\title{
Contradiction Between Law and Sub-Rules With Psychological Consideration
}

\section{Contradicción entre la ley y las subreglas con consideración psicológica}

\author{
Tatiana L. Shklyar * \\ Plekhanov Russian University of Economics, Russia \\ ORCID: https://orcid.org/0000-0002-0888-6307 \\ Anna V. Popova \\ Financial University, under the Government of the Russian Federation, Russia \\ ORCID: https://orcid.org/0000-0003-3713-606X \\ Svetlana S. Gorokhova \\ Financial University, under the Government of the Russian Federation, Russia \\ ORCID: https://orcid.org/0000-0001-8609-0294
}

Recibido 05-12-19 Revisado 16-01-20 Aprobado 17-04-20 En línea 27-04-20

Correspondencia

Email: tlb@mail.ru
Citar como:

Shklyar, T. L., Popova, A. V., \& Gorokhova, S. S. (2020).
Contradiction Between Law and Sub-Rules With Psychological
Consideration. Propósitos y Representaciones, 8(3). doi:
http://dx.doi.org/10.20511/pyr2020.v8n3.514

(C) Universidad San Ignacio de Loyola, Vicerrectorado de Investigación, 2020. 


\section{Summary}

In this article authors suggest to consider features of hybrid reality, both in psychology, and in law. Authors investigate opportunities and dangers of the virtual world. Reveal the main psychological aspects provoking the person to plunge into Internet space. Also in article the main tendencies and the directions of transformation of the modern legislation connected with need to provide a condition of information security for the individual, societies, and the states in general are shown, difficulties of implementation of legal regulation and administrative control in digital space are analyzed, and the appeal of the virtual world to inhabitants, including, and in connection with his weak accountability from is at the same time proved out of.

Keywords: Personality; Hybrid Reality; Psychology; Law.

\section{Resumen}

En este artículo, los autores sugieren considerar las características de la realidad híbrida, tanto en psicología como en derecho. Los autores investigan las oportunidades y los peligros del mundo virtual. Revele los principales aspectos psicológicos que provocan que la persona se sumerja en el espacio de Internet. También en el artículo se muestran las principales tendencias y las direcciones de transformación de la legislación moderna relacionada con la necesidad de proporcionar una condición de seguridad de la información para el individuo, las sociedades y los estados en general, las dificultades de implementación de la regulación legal y el control administrativo en digital se analizan los espacios, y se demuestra al mismo tiempo el atractivo del mundo virtual para los habitantes, incluidos y en relación con su débil rendición de cuentas.

Palabras clave: Personalidad; Realidad Híbrida; Psicología; Derecho.

\section{Introduction}

Modern society is in the 21st century now, no matter how it is evaluated from the standpoint of various researchers belonging to various branches of human knowledge, primarily perceived through the prism of cross-border, global information technologies and resource impact on it. The society, giving rise to this phenomenon, experiences more and more the effects of a continuously increasing, becoming more accessible, and almost uncontrolled flow of information. We can't imagine of our daily life and work without the presence of high information technologies, and even temporary separation from personal communication devices, the access to network resources and electronic services provided by both the state and private companies, turns out to be an extremely serious problem for us. Moreover, unforeseen failures in the work of information systems can paralyze the life and the activity not only one person, but the whole society, and the state as a whole. In some cases, there is no alternative. We become addicted to the opportunities, the amenities and the pleasures of the digital age. But, besides the obvious advantages, technological dependence, harbors a number of dangers and threats like any other dependence. Therefore, being on the verge of the "knowledge society" development (Decree of the President of the Russian Federation of May 9, 2017 № 203), obviously, one should not forget that "there are many sorrows in many knowledge".

Newly created technologies influence society and change individuals, and this trend is not always positive. Hybrid reality has become an integral part of our life, as the union of the real and virtual worlds, where physical and digital objects coexist and interact in reality (What is hormone dopamine). That is why it is so important to study this new reality of humanity comprehensively, which can change the image and the perception of the reality around us forever. 


\section{Pros and Cons of Hybrid Reality}

Nowadays, it is impossible to imagine modern technologies outside the hybrid reality. Engineering areas (construction, aircraft modeling, car industry, etc.), medicine, chemistry, education, and of course the economy (online stores) use the hybrid reality. It is the hybrid reality that helps to visualize objects/processes, reduces the time for the development and the implementation of new technologies. Mixed reality allows you to speed up technological, production, commercial and other processes and make them more efficient; It provides the opportunity to implement their ambitions and earn capital with minimal investment.

For people with disabilities who experience objective difficulties in the interaction with the real world outside their own home, this is an excellent option to live a full life: learn, work and fulfill the need for communication, and therefore become worthy representatives of modern society. The virtual world helps to conquer social isolation and opens new horizons. For ordinary people, the World Wide Web can be useful in the selection of goods (online shopping), image (hair and clothing selection programs), information, the search for friends (social networks), training (webinars), etc. All this can be used in the future for the benefit of oneself and others in the real world.

However, each medal has two sides. And if we talk about the minuses of the hybrid reality, it is necessary to delve into the essence of this issue and understand how the process works from the inside (see Fig. 1).

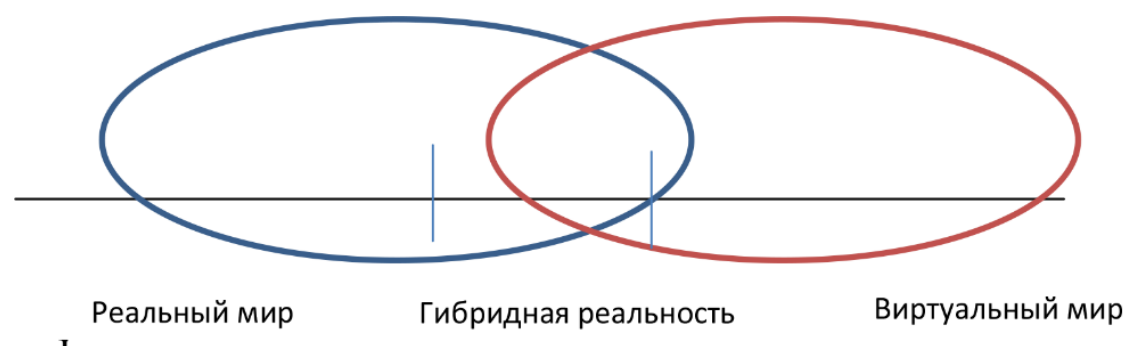

Figure 1. Combination of worlds (the author's point of view)

To begin with, the authors of this article propose to consider how a person changes under the influence of mixed/hybrid reality.

\section{Dopamine Addiction}

Dopamine (DA) (see Fig. 2) - (pleasure hormone) is a neurotransmitter that performs several tasks, such as:

- creates an anticipation of happiness;

- fixes the situation of success;

- motivates for further actions (for the purpose of pleasure obtaining);

- helps to make a quick choice;

- improves memory and concentration;

- facilitates the switching of attention in the process of mental work;

- regulates motor activity;

- stimulates the enjoyment (). 


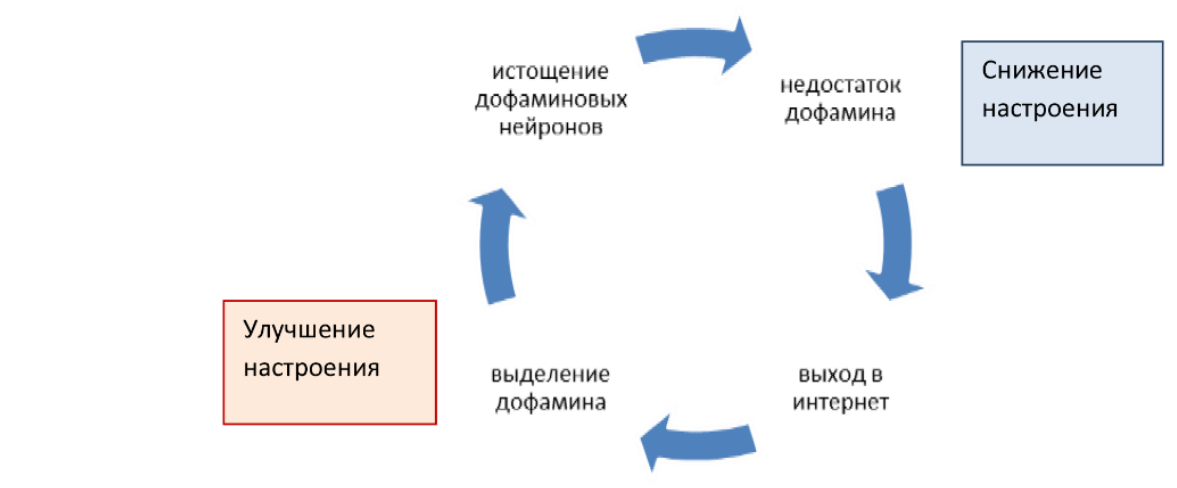

Улучшение пастроеиия - Mood enhancement / Истощение дофаминовых нейронов - Depletion of dopamine neurons / Недостаток дофамина - Dopamine deficiency / Снижение настроения - Bad mood / Выход в интернет - Internet access / Выделение дофамина Dopamine release

Figure 2. The mechanism of dopamine dependence development on the Internet (author's interpretation)

It's the dopamine addiction that forces an individual to spend more and more time on the world wide web, very often without benefit for a person, "eating" his time, not giving the awareness of what is happening and without introducing any meaning. Intellectual stagnation occurs, a person ceases to develop, succumbing more and more to the influence of virtuality, irretrievably losing the time of his real life (the author's interpretation).

\section{Existential Impact}

Existential psychology is the trend in psychology that proceeds from the uniqueness of an individual life (The leading concept of the existential psychology). It is based on four fears: the fear of lack of meaning in life, the fear of loneliness, the fear of death and the fear of choice. The greatest interest for this article, according to the authors, is the fear of existential loneliness. Existential loneliness is the inevitable reality of human existence, "the gulf between oneself and the others, through which there are no bridges," the impossibility to divide the inner world of an individual (Yalom, 2015). Each person appears and leaves this world alone. Everyone experiences this feeling throughout his life and tries to level it through society, family, etc., hiding in the crowd from sadness and longing, realizing that no one can understand him completely. With the advent of social networks, the escape from loneliness has moved to virtual pages. The virtual crowd has replaced the living people and "human" communication. Surrogate communications create the appearance that someone is interested in a person, his life, his thoughts ... But this is only the illusion that helps to reduce fear temporarily.

When a free minute appears, people immediately plunge into a virtual community, where the world lives by its own rules and every moment some information appears. It is possible to get a response by posting personal news. This response is insignificant in reality most often, but it is so necessary for an individual, confirming that he is not alone, that he is needed and someone is interested in him.

\section{Cognitive Influence}

Cognitive psychology is aimed at the study of human psyche cognitive processes (Druzhinin \& Ushakov, 2002). At that the authors propose to limit the consideration of the basic belief "dislike". Basic beliefs are the key ideas of a person about himself, this is the basic level of beliefs (http://becmology.ru). Every living thing needs "love." And if, before the immersion of a real person in the virtual world, the desire to satisfy this need prompted the actions aimed at helping others, at heroic deeds, etc., made in the hope to receive "stroking" in the form of words of 
encouragement, support and much more, then this is realized through the collection of "likes" and "friends" in the virtual world, many of which are unknown to an individual. A modern man refuses to interact with people in reality in favor of a safer and simpler virtual communication. Where there is some time to think, to correct what was written: where you can retouch your image, embellish the inner world, transform your thoughts, and thereby attract a large audience of loyal characters, or the same people who are looking for "love".

Is there an easier way? It is enough to post an outstanding image for the virtual world - a photo in order to get a positive response. This is not enough in the real world. Like is the basic means of approval in social services (http://www.wikireality.ru). And the more sophisticated the message, the more response it receives. Looking through the news feed in social networks, on news portals, you immerse yourself in the perverted world of humanity. Normal manifestations instantly drown in the news flow and only unusual (often negative, such as aggression, violence, catastrophes and pornography) remain on the surface (https://miridei.com). The new world produces new diseases. Like-dependence is the disease born by the hybrid reality. The lack of likes is equated with social death, the rejection by society (Like me! Why we depend on social media approval), plunging the post holder into an extremely depressed state.

\section{Desire to Be Better Than Others}

Adler's individual psychology is based on the determinant development of a personality, his desire for power, which has been present in a man since birth (Adler, 2015). Every individual wants to be significant. In what way a modern person can get recognition in a hybrid reality? Do the mechanisms of the past work in modern times? Every time has its own heroes! So who is the hero of our time? A poet, an artist, a scientist, a military man? Or the one who, risking his life, fills the content with extreme photo and video materials? Maybe the one who is realized by attracting the commoners to his private life?

A person can become significant in two ways:

1. To state about himself in society;

2. To subordinate others with the aim of self-assertion.

Social networks have simplified this process greatly. SMM users compete in resourcefulness, courage, and insanity while creating self-shots (see Figure 3). Self-shot a snapshot of yourself (using a smartphone / a mobile phone) and then this snapshot is posted in social networks (https://www.drive2.ru).

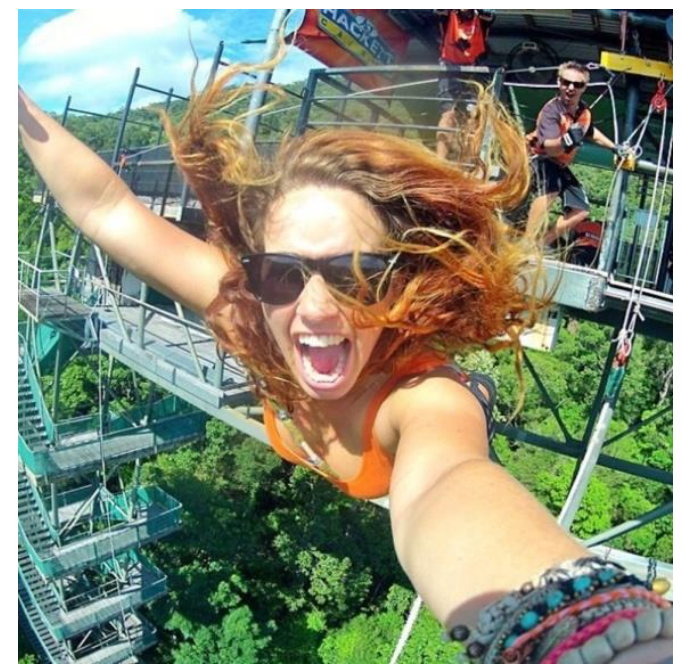

Figure 3. Crazy and original selfies (http://batona.net) 
The first message about death due to selfie was published by the media in March 2014 . Since then, 127 people died during self-shooting process: in 2014 there were 15 cases, in 2015 39 , and 73 during the first eight months of 2016. India became the record for the number of deaths in the process of taking selfies - 76 residents of the country suffered in 2017. Pakistan occupies the second place: 9 cases. The United States occupies the third place - 8 deaths in the same year (https://hi-tech.mail.ru). Such an insecure method perfectly implements the first option (and it is much easier than to win at the Olympics or to get an Oscar).

It is possible to assert oneself at the expense of a large number of subscribers. Pavel Durov (6000000); Ivan Rudskoy (2300000); Katya Clap (1600000) et al. became famous because of subscribers (https://fishki.net). The more subscribers, the more influence a person has on people. His audience is watches what he eats, where he rests, what he wears. He has followers who perceive this individual as an idol, as the last instance in complex issue solution. According to the authors of this article, these people are far from ideal very often.

\section{Life Frustration}

Logotherapy is the type of psychotherapy based on the search and the analysis of existence meanings (http://gormons.ru). And here it is necessary to refer to the quote of logotherapy founder, Viktor Frankl: "animal instincts do not tell the modern man what he needs, and the traditions of the ancestors do not teach him what he should do any longer. And so, without knowing what he needs and how he should live, an individual cannot understand what he wants often" (Frankl, 2016). A modern man suffers from boredom (existential vacuum), as well as from modern disease (there is no need to look for food, to protect offspring, etc.), which he fills with the viewing of pages in social networks.

The complete absence of the meaning of life plunges society into various variants of frustration (the author's interpretation):

1. The acceleration of the pace of life, due to the maximum immersion in work;

2. The compensation through love (usually manifested in sexual promiscuity);

3. In sufferings, very often not based on anything, connected with inner emptiness;

4. In various dependencies: shopping addiction; alcoholism; drug addiction, etc.

5. The departure from reality in the virtual world.

As we can see, modern society offers a cure from frustration - a hybrid reality that creates only a temporary illusion, aggravating the symptoms of the disease. However, the immersion into the virtual world is considered by many to be the safest option of all of the abovementioned ones. The immersion into virtual reality cannot but remain unnoticed when a person creates his own "twin" in the Internet with his own hands, he begins to act according to the avatar image unknowingly. Avatar is a graphic or a real image used by users on their Internet sites to present themselves in the virtual world (http://geek-nose.com).

For a more complete understanding of the problem, let us turn to the theory of Carl Rogers (Fraser \& Feidmen, 2007). Rogers does not divide people into healthy and sick ones; instead, he writes about the ability of people to perceive their real situation and introduces the concept of congruence, the correspondence of the real world to communications, experience and personal awareness of an individual about his inner self. Accordingly, the more the real person incongruent to his "Avatar" (the author's interpretation), the more he experiences stress and anxiety. Most of the symptoms described in the psychopathology literature will be appropriate for these people. At the same time, the internal state of a person will strive for balance, minimizing incongruity as much as possible. However, the difference between the real and the virtual world does not allow to implement it, causing more and more psychological discomfort. 


\section{Law System and Hybrid Reality}

Based on the foregoing, virtual space and virtual reality should become a separate object of legal regulation, since they provide individuals with the opportunity to exercise almost all rights and freedoms in any sphere of public relations. However, the virtual space can attract criminals due to the difficulty of illegal action finding and punishing in virtuality. Therefore, the task of the legislation is not only to define the rules of virtual space user interaction, but also to protect their rights from violations in the area of not only public but also private law, and, above all, in the field of information and information services. At the same time, it is important to protect both the individual rights of each user and the collective rights of the virtual community, as "the groups of people using the network for communication and interaction, as well as the set of connections between them" (Castels, 2000).

The complexities of the virtual reality legal support lies in the fact that the peculiarity of social relations that Internet users have is transboundary in nature. After all, virtual space cannot be fixed as a sovereign territory of a state; a foreign element is present necessarily in the characterization of legal relations, which complicates the implementation of legislation in this area. Therefore, in addition to international law, which is implemented in the domestic law of the country only if it is ratified by the legislative (representative) authorities of each individual state, a system of domestic legislation is needed to protect a citizen from the attacks on his rights and freedoms.

Some countries solve this problem by complete prohibition of their citizen access to the Internet (North Korea, the Republic of Cuba, etc.), others strictly censor the virtual space. An example of this is the "PRC Cybersecurity Act" adopted on June 1, 2017, which obliges "operators to create an internal security management system, to take preventive measures against computer viruses and network attacks. They are instructed to monitor and record the status of the network and technical measures to resolve network security issues and store reports for at least six months from the date of their creation. Network product and service providers are prohibited from installation of "malware", they are responsible for the timely warning of any risks to users and the relevant authorized bodies." The anonymity of users is prohibited, and the state attaches a special importance to the protection of national security and society interests (Kirillov \& Selishchev, 2018). To this end, since the end of September 2017, WhatsApp was blocked on the territory of the PRC, and since March 31, 2018, they blocked the access to the virtual private networks (VPN) not approved by the government.

\section{National Security and Hybrid Reality}

Taking into account the importance and the danger of modern information and technological realities that we described earlier, the Russian legislator has given a considerable attention to the issue of information society development and the information security provision in the Internet environment. Certainly, the key role in social relation regulation in the implementation of the right to information, the application of information technologies, and the protection of information is played by the Federal Law "On Information, Information Technologies and Information Protection" adopted on July 27, 2006, (Federal law of 27.07.2006 N 149-FZ) which standardized the categorical conceptual apparatus used in this area of legal relations, established the fundamental approaches to the legal impact on them, and also determined other, most important elements of a specified object right regulation.

The Doctrine of RF Information Security, approved by the Decree of RF President on December 5, 2016 (The decree of the President of the Russian Federation from 05.12.2016 No. 646), as the system of official views o Russia national security provision in the information 
sphere, establishes a detailed definition of information security, by which it proposes to understand the state of individual, society and the state protection from internal and external informational threats, which ensure the implementation of the constitutional rights and freedoms of a person and a citizen, worthy citizen life quality, sovereignty, territorial integrity, sustainable socio-economic development, defense and state security.

\section{Informational Environment and National Interests}

Speaking about the national interests of Russian Federation in the information sphere, the Doctrine of Information Security, namely the subparagraph a) of paragraph two, section I. "General provisions", states that those are the objectively important needs of an individual, society and the state for their security and sustainable development provision in the part concerning the information sphere.

In its turn, the information sphere, as follows from the clause 1 of the same section, is the set of information, objects of informatization, information systems, the sites in the information and telecommunication network "Internet", communication networks, information technologies and the entities whose activities are related with the formation and the processing of information, the development and the use of these technologies, ensuring information security, as well as a set of mechanisms for relevant public relation regulation.

In more detail, the content of Russian Federation national interests in the information sphere is disclosed by the section II of the Doctrine under consideration, which is dedicated specifically to this issue. Thus, developing the gradation of the national interests of Russian Federation in the information sphere, the Information Security Doctrine puts in the first place (the sub-clause a), the clause 8 of the part II) the provision and the protection of the constitutional rights and freedoms of a person and a citizen in terms of information receiving and use, the inviolability of private life during information technology use; as well as the provision of information support for democratic institutions, the mechanisms of interaction between the state and civil society, as well as the use of information technologies in the interests of cultural, historical, spiritual and moral value preservation for the multinational people of Russia (Molchanov \& Matevosova, 2017). As you can see, in this case the thing is about the primacy of the individual and society interests in the structure of the determined national interests, which is fully consistent with the system of values established by RF Constitution. However, it should be remembered that under certain circumstances the interests of a person, the society and the state may conflict with each other, which leads to the conflict of interests, with a further obvious revision of priorities (state/society/citizen) (Gorokhova, 2018).

Thus, the state tries to cross systematically the illegal and potentially harmful activities of both the users of the virtual space and the site organizers and bloggers who have placed information that is prohibited for dissemination, the discrediting of a person's honor and dignity or which is harmful to the user. However, an effective implementation of this activity is hampered by a number of factors which RF Information Security Doctrine qualifies as information security threats.

What are these factors (threats)? For the simplicity of perception and to make these threats systematic, we divide them into two units - the threats from the outside, and threats of an internal or a mixed nature. Let's consider the external threats first of all. The Doctrine considers as such: 1) the building up information and technical impact on information infrastructure by foreign countries for military purposes, while simultaneously enhancing the activities of organizations engaged in technical intelligence concerning Russian state bodies, scientific organizations and defense industry enterprises; 2) the expansion of foreign special service means use to provide information and psychological impact on the population (primarily young people, in order to 
erode the traditional Russian spiritual and moral values); 3) the increase in the scale of information technology use by individual states and organizations for military-political purposes aimed at the undermining of sovereignty, political and social stability, and territorial integrity of Russian Federation and its allies; 4) the increase of complexity, scale and the coordination of computer attacks on the objects of critical information infrastructure; 5) the desire of individual states to use technological superiority to dominate the information space.

Summarizing all of the mentioned above, we can conclude that there is only one external threat to information security, and it boils down to the buildup of the information impact by some foreign countries (established on the basis of technological superiority) on all spheres of state and public life carried out by means of intelligence, espionage, computer attacks, as well as psychological impact on citizens, in order to damage sovereignty, territorial integrity, political and social stability of Russian Federation. One should note here and the increase of computer crime, especially in the credit and financial sphere, as well as the increase in the number of crimes related to the violation of constitutional rights and freedoms of a person and citizen, also in relation to the inviolability of private life, personal and family secrets during the processing of personal data by the use of information technologies.

Considering the seriousness and the danger of external threats to information security in the situation of growing volume and the increase of hybrid reality importance in the life of an individual, society and the state, the efforts of the state and society to ensure information security in the framework of this new reality should be concentrated on internal problems, because, first of all, they are more amenable to adjustment and overcoming than external threats existing objectively and independently beyond our will. Secondly, the elimination of internal problems will largely depend on the effectiveness of external threat countering, and thirdly, "technological lag, dependence means the reduction of the security and the economic capabilities of the country, and, thus, the loss of sovereignty" (Raskin, 2016). Of course, this is the worst situation of all possible scenarios.

Thus, in our opinion, it is necessary to refer to the statements by R. Cialdini: "As soon as a person takes an obvious position for others, he has the desire to adhere to it in order to look consistent, especially if it is manifested publicly" (Cialdini, 2017; Fedyunin \& Shilina, 2017; Lipina et al., 2017). The properties of virtual reality are so ambiguous that deep immersion into it can be detrimental to an individual, increasing incongruence, as demonstrated in the article. The desire to stick to "Avatar" is not always feasible, which can lead to a complete psychological transformation of an individual in the real world. The hybrid reality is attractive, but if you ignore its dangers and do not respond to the threats emanating from it, it can become the time bomb for humanity, which should not be forgotten during the promotion of modern technologies in the worldwide network.

It should be remembered that a person is only a part, a member of society. He is associated with his state, and depends largely on it. Therefore, thinking about the psychological safety of an individual, his security in the information environment that forms the body of virtuality, one should not overlook the issues of information security legal support for the relevant society and the state, since only such an integrated approach is able to ensure an effective resolution of hazard problems and their prevention, the emergence of which is directly or indirectly associated with the advent of hybrid reality era

\section{References}

Adler, A. (2015). The Practice and theory of individual psychology. From: Academic Project, Gaudeamus.

Beckology http://becmology.ru/default.htm (date accessed: 09.01.2018)

Propósitos y Representaciones 
Castels, M. (2000). Information age: economy, society and culture. Moscow: GU VSHE, https://litportal.ru/avtory/manuel-kastels/kniga-informacionnaya-epoha-ekonomikaobschestvo-i-kultura-735876.html (accessed 03.04.2018)

Cialdini, R. (2017). Psychology of influence. Moscow: Publishing house "E".

Community: This is interesting https://www.drive2.ru/c/2219679/ (accessed: 01.08.2018)

Crazy and original selfie http://batona.net/57725-samye-bezumnye-i-originalnye-selfi-27foto.html (date accessed: 09.01.2018)

Decree of the President of the Russian Federation of May 9, 2017 № 203 "on the Strategy of the information society in the Russian Federation for 2017-2030", http://pravo.gov.ru/proxy/ips/?docbody=\&nd=102431687 (date of application: 15.02.2018)

Druzhinin, V. N., Ushakov, D. V. (ed.) (2002). Cognitive psychology. M, - 480 p.

Federal law of 27.07.2006 N 149-FZ (as amended on 25.11.2017)"on information, information technologies and information protection". (2006). Assembly of the legislation of the Russian Federation, 31 (Part 1). St. 3448

Fedyunin, D., \& Shilina, M. (2017). In Russia for the first time: young researchers discuss communication and big data. Russian Journal of communication, 9(3), 307-308.

Frankl, V. (2016). Suffering from the meaninglessness of life. Siberian University publishing house.

Fraser, R., \& Feidmen, D. (2007). Humanistic, transpersonal and existential psychology Rogers K., Maslow A., may R. St. Petersburg «Prime-EUROSIGN».

Gorokhova, S. S. (2018). On some aspects of information security in the Russian Federation. Modern lawyer, 2(23), 128-138.

Kirillov, A., \& Selishchev, A. (2018). Cybersecurity in Chinese in the PRC shall enter into force the new law on the Internet. URL: http://tass.ru/mezhdunarodnaya-panorama/4290068 (accessed 02.04.2018)

Like http://www.wikireality.ru/wiki/Лайк (date accessed: 09.01.2018)

Like me! Why we depend on social media approval https://www.cosmo.ru/psychology/psychology/laykni-menya-pochemu-my-zavisim-otodobreniya-v-socsetyah/(date of application: 09.01.2018)

Lipina, S. A., Lochan, S. A., Fedyunin, D. V., \& Bezpalov, V. V. (2017). Government promoting communication tool in innovation development of companies. European Research Studies Journal, 20(4B), 536-547.

Molchanov, N., \& Matevosova, K. E. (2017). Doctrine of information security of the Russian Federation (new law). Actual problems of Russian law, 2(75), 159-164

Raskin, A. V. (2016). Network technologies in hybrid warfare. Information Warfare, 1(37), 2-5.

The 20 most popular social media posts and their true value https://miridei.com/sucessideas/success-

secrets/posty_na_fejsbuke_chto_my_pishem_vs_chto_my_na_samom_dele_dumaem/ (accessed: 09.01.2018)

The decree of the President of the Russian Federation from 05.12.2016 No. 646 "About approval of the information security Doctrine of the Russian Federation". (2016). Collected legislation of the Russian Federation, 50. St. 7074

The leading concept of the existential psychology https://studfiles.net/preview/4366022/ (accessed: 03.01.2018)

The number of deaths because of selfie has increased several times https://hitech.mail.ru/news/selfie-death-statistics/(accessed: 09.01.2018)

What is an avatar on the Internet? Where to use and how he appeared http://geek-nose.com/chtotakoe-avatar-v-internete/ (accessed: 09.01.2018)

What is hormone dopamine http://gormons.ru/gormony/dofamin/chto-takoe-gormon-dofamin/ (accessed 14.03.2018)

Who has more subscribers Vkontakte? https://fishki.net/2100199-u-kogo-bolyshe-vsegopodpischikov-vkontakte.html (date accessed: 09.01.2018) 
Yalom, I. (2015). Existential psychotherapy Moscow: «Class». 